Jolanta Dybała (Łódź)

(iD) https://orcid.org/0000-0002-5635-5834

Krzysztof Jagusiak (Łódź)

(iD) https://orcid.org/0000-0003-3751-7882

Michał Pawlak (Łódź)

(iD) https://orcid.org/0000-0001-6525-3576

\title{
Titus Flavius Clemens' Stance on Wine as Expressed in Paedagogus
}

$\mathrm{T}$ he aim of this article is twofold. Firstly, it is to present what Titus Flavius Clemens, a philosopher and Christian theologian from the period of $2^{\text {nd }}-3^{\text {rd }}$ century AD, thought about the subject of wine. Secondly, we aim to present his recommendations referring to various issues relating to the consumption of this drink. The analysis is based on Paedagogus. This work is an important source of information on the contemporary environment of Clement and of Alexandrian Christians, their behaviors and customs, as well as, importantly, their attitude to the rigorous requirements of the new faith.

Clement of Alexandria was born around 150 AD to a pagan family, most likely in Athens ${ }^{1}$. He probably started his education in his hometown, and in order to continue it he traveled a fair amount, visiting Italy, Syria and Palestine. Around

\footnotetext{
${ }^{1}$ For more information on Clement cf. i.a.: B. Altaner, B. Stuiber, Patrologia, trans. P. Pachciarek, Warszawa 1990, p. 277-284; J. Niemirska-PliszczyńsKa, Wstęp, [in:] Klemens Aleksandryjski, Kobierce zapisków filozoficznych dotyczących prawdziwej wiedzy, vol. I, trans. et ed. EADEM, Warszawa 1994, p. VII-XI; J. Naumowicz, Wstęp, [in:] Klemens Aleksandryjski, Który człowiek bogaty może być zbawiony?, trans. J. Czuj, ed. J. Naumowicz / Pseudo-Klemens, Zachęta do wytrwałości, trans. et ed. J. Naumowicz, Kraków-Ząbki 1995, p. 5-7; H. von Campenhausen, Ojcowie Kościoła, trans. K. WierszyŁowski, Warszawa 1998, p. 28-36; C. Vidal Manzanares, Klemens Aleksandryjski, [in:] IDEM, Pisarze wczesnochrześcijańscy I-VII w., trans. E. BursKa, Warszawa 2012, p. 116-117; J. Wojtczak, Klemens Aleksandrinos, [in:] Słownik pisarzy antycznych, ed. A. Świderkówna, Warszawa 2001, p. 289-290; M. Kowalewska, P. Szczur, Klemens Aleksandryjski, [in:] Powszechna Encyklopedia Filozofii, vol. V, ed. A. KrąPiec, A. MaryniarczyK, P. Jaroszyński, Lublin 2004, p. 637-641; E. Osborn, Clement of Alexandria, Cambridge 2005; P. Ashwin-Siejkowski, Clement of Alexandria. A Project of Christian Perfection, London 2008, p. 19-28. Some scholars claim that Clement was born ten years later, cf.: P. Karavites, Evil - Freedom - and the Road to Perfection in Clement of Alexandria, Leiden-Boston-Köln 1999, p. 4.
} 
$180 \mathrm{AD}$ he came to Alexandria, where he spent the following two decades. In this city, he became a student of Pantainos, the founder of the Alexandrian School of Theology, where both evangelical teaching and Greek philosophy were studied $^{2}$. Although Clement took over the school leadership after Pantainos he did not stay in Alexandria until the end of his life. He had to leave the city due to persecutions of Christians which took place under Septimius Severus in 202 or 203 AD. He was given shelter by his student and friend Alexander, who later became the bishop of Jerusalem. The further fate of Clement is unknown and we only know that he died about 10 years after leaving Egypt. Although Eusebius of Caesarea describes Clement as a priest, this matter is still under debate ${ }^{3}$.

The most prolific period of Clement's life was during his stay in Alexandria. From his rich literary legacy only three pieces and one homily survived to this day ${ }^{4}$. One of them is Paedagogus which consists of three books and which is addressed to pagans who have converted to Christianity. Its purpose is to strengthen and deepen their faith. The Paedagogus is Christ himself. The first part of the work is a theoretical reflection on Christian ethics, and the next two give a series of detailed rules relating to the daily conduct appropriate for Christians.

Clement's opinions about wine can be considered with respect to three aspects - moral, medical and culinary. Having analyzed them, we want not only to focus on his views on the topic that is at the center of this paper, but also to find answers to three important research questions. First of all, we want to check whether the Alexandrian's position on wine consumption departs from the stance formulated by other Christian writers who were his contemporaries. We use the example of John Chrysostom here. Secondly, we aim to verify Clement's opinions referring to the medical effects of drinking wine with the science of professionals, that is, contemporary doctors. The final question pertains to the breadth of knowledge about ancient cooking, specifically related to wine, which is offered to us by Clement in his Paedagogus.

Before going into a detailed discussion of Clement's views on wine, let us briefly consider the role that wine played in the life of ancient Mediterranean societies. It certainly reached far beyond its role as a beverage. Ever since the old (elusive from today's perspective) times, when wild vine was used, to thousands of years later, already in the eneolite when vine was domesticated, it was processed in order to

\footnotetext{
${ }^{2}$ More on Pantainos and his school: C. Vidal Manzanares, Panten, [in:] idem, Pisarze wczesnochrześcijańscy..., p. 146; E. OsBorn, Clement of Alexandria..., p. 19-24.

${ }^{3}$ B. Altaner, B. Stuiber, Patrologia..., p. 277; J. Naumowicz, Wstep..., p. 6-7; P. Karavites, Evil..., p. 5; E. Osborn, Clement of Alexandria..., p. 14-20; M. Szarmach, Wstęp, [in:] Klemens Aleksandryjski, Wychowawca, trans. et ed. M. Szarmach, Toruń 2012, p. 7-11.

${ }^{4}$ Cf. e.g.: B. Altaner, B. Stuiber, Patrologia..., p. 278-281; H. von Campenhausen, Ojcowie Kościoła..., p. 3-34; P. Karavites, Evil..., p. 5-8; E. Osborn, Clement of Alexandria ..., p. 5-15; P. AshWIN-SiejKowski, Clement of Alexandria..., p. 28-29.
} 
obtain wine in the Middle East and the Caucasus (among others) ${ }^{5}$. With the passage of time, the popularity of wine slowly increased along with the expansion of the areas of its cultivation. In the era of Greco-Roman domination in the Mediterranean area, which is of particular interest here, this beverage became by far the most important one, next to water.

Wine was as indispensable part of the daily menu, in which it was an invaluable source of sugar and calories, and at the same time a product of such fundamental importance that it was considered to be of the same importance as cereals and oil, whose consumption constituted a determinant of belonging to the civilized world ${ }^{6}$. It was also an essential element in the process of socialization, for example on the occasion of Greek symposiums and syssitia, or participation in religious holidays during which wine was offered in sacrifice and drunk (symposia were also connected with sacrum $)^{7}$. It also played an important role in large-scale trade (albeit obviously fluctuating), both local and between distant lands (types of wine which were in special demand were profitable for merchants to transport over enormous distances) $)^{8}$. Finally, wine was widely used in contemporary

\footnotetext{
${ }^{5}$ Cf. D. Zohary, M. Hopf, Domestication of Plants in the Old World. The Origin and Spread of Cultivated Plants in West Asia, Europe, and the Nile Valley, Oxford 1993, p. 143-150; D. Zohary, The Domestication of the Grapevine Vitis vinifera L. in the Near East, [in:] The Origins and Ancient History of Wine, ed. P.E. McGovern, S.J. Fleming, S.H. Katz, Amsterdam 1996, p. 23-30; T. Unwin, Wine and the Vine. An Historical Geography of Viticulture and the Wine Trade, London-New York 1996, p. 47-63; D.L. Thurmond, From Vines to Wines in Classical Rome. A Handbook of Viticulture and Oenology in Rome and the Roman West, Leiden-Boston 2017, p. 6-15.

${ }^{6}$ For more on the use of wine in cooking in antiquity see e.g. A. DALBy, Food in Antiquity from A to Z, London-New York 2003, p. 350-352; J.M. Wilkins, S. Hill, Food in the Ancient World, Malden-Oxford 2006, p. 166-184; M. Кокоszко, K. JAGUsiak, Woda, wino i tak dalej, czyli o napojach i trunkach w Konstantynopolu, PNH 9, 1, 2010, p. 37-48; T. Boulay, Wine Appreciation in Ancient Greece, [in:] A Companion to Food in the Ancient World, ed. J. Wilkins, R. Nadeau, Malden-Oxford 2015, p. 271-282; D.L. Thurmond, From Vines..., p. 3-4, 218-245.

${ }^{7}$ The literature on the cultural and religious role of wine is rich and what we follow is the just the fraction of it. Cf. N.R.E. Fisher, Drink, Hybris and the Promotion of Harmony in Sparta, [in:] Classical Sparta. Techniques behind Her Success, ed. A. Powell, London 1989, p. 26-50; T. Unwin, Wine and the Vine..., p. 63-66; L. Nevett, Domestic Space in Classical Antiquity, Cambridge 2010, p. 59-63; M. Węcowski, Sympozjon, czyli wspólne picie. Początki greckiej biesiady arystokratycznej (IX-VII wiek p.n.e.), Warszawa 2011, passim; I. KACzor, Deus - ritus - cultus. Studium na temat charakteru religii starożytnych Rzymian, Łódź 2012, p. 42-45, 94-95, 102-103, 105, 110-113, 128-135, 174, 199-200, 202, 220, 226-227, 235-236, 253, 263-265, 278, 290-291, 313; S. Corner, Symposium, [in:] A Companion to Food..., p. 234-235; P. Halstead, Food Production, [in:] A Cultural History of Food in Antiquity, ed. P. ERDKAmp, London-New York 2016, p. 27-28.

${ }^{8}$ Cf. V.R. Grace, Amphoras and the Ancient Wine Trade, Princeton 1979, p. 21-31; N. Purcell, Wine and Wealth in Ancient Italy, JRS 75, 1985, p. 1-19; P.R. SEALEy, New Light on the Wine Trade with Julio-Claudian Britain, Brit 40, 2009, p. 1-40; W. Broekaert, A. Zuiderhoek, Food Systems in Classical Antiquity, [in:] A Cultural History..., p. 45-46, 53-54.
} 
medicine, as evidenced by numerous passages from the works of e.g. Dioscorides, Galen, or Rufus of Ephesus?.

The last of these issues, due to the aims of this article, deserves some more discussion because the wine in ancient Greek-Roman medicine was thoroughly described, along with detailed dietary characteristics. It is impossible to present it comprehensively here without breaking the reasonable framework of the introduction, yet a few issues are worth noting. As far as we can ascertain, on the basis of preserved sources, in the first centuries after Christ there was consistent medical knowledge concerning wine which had been accepted for several centuries by most doctors ${ }^{10}$ and intellectual circles who were not professionally connected with medicine ${ }^{11}$. At the time, wine was considered as having various properties and medical applications depending on its age, color, taste (and degree of dryness), density ${ }^{12}$, and it was believed it could have different effects on people depending on the characteristics of their organisms ${ }^{13}$.

Before we turn to the analysis and the research questions formulated above, let us briefly consider the importance of wine for Jews (and, consequently, for the first Christians). It can be said that it was fundamental, because grapes - just like for other ancient peoples of this area - were one of the basics of diet, agriculture, processing and trade. Wine (and grape) also played a significant religious

\footnotetext{
${ }^{9}$ Cf. e.g. R. Alessi, Le vin dans les Épidémies d'Hippocrate, [in:] Vin et santé en Grèce Ancienne. Actes du Colloque organisé à l'Université de Rouen et à Paris, 28-30 septembre 1998, ed. J. JounannA, L. Villard, Athènes 2002, p. 105-112; D. BÉGuin, Le vin médecin chez Galien, [in:] Vin et santé..., p. 141-154; K. JAGUSIAK, Zastosowania buraka (Beta vulgaris L.) w sztuce medycznej grecko-rzymskiego antyku i wczesnego Bizancjum (II-VII w.), [in:] Lek roślinny, vol. IV, ed. B. PŁonka-SyrokA, A. Syroka, Wrocław 2015, p. 41-43; Z. Rzeźnicka, M. Koкoszko, Czosnek w medycynie wczesnego Bizancjum na przykładzie pism Orybazjusza, [in:] Lek roślinny, vol. IV..., p. 56-57, 59-60; M. Koкоszко, Enologia Dioskuridesa, czyli kilka uwag na temat leczniczego działania wina, [in:] Historia panaceum. Między marzeniem a oszustwem, ed. W. Korpalska, W. ŚlusarczyK, Bydgoszcz 2016,

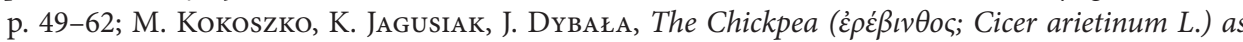
a Medicinal Foodstuff and Medicine in Selected Greek Medical Writings, SCer 7, 2017, p. 110-112,

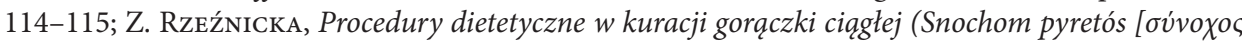

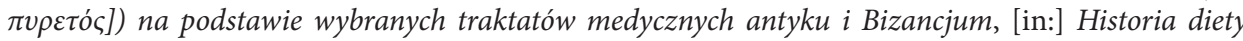
i kultury odżywiania, vol. I, ed. B. PŁonka-Syroka, H. Grajeta, A. Syroka, Wrocław 2018, p. 51-52. ${ }^{10}$ This is evidenced by similarities which can be found in preserved texts, often resulting directly from the literal citation of their predecessors by medical writers, e.g. Oribasius $\left(4^{\text {th }} \mathrm{c}\right.$.) quoted in his passages relating to wine, among others. Rufus of Ephesus (Oribasii collectionum medicarum reliquiae, V, 7, 1, 1 - 7, 3; V, 9, 1, 1 - 3, 2; V, 12, 1, 1 - 3, 3, vol. I-IV, ed. I. RAeder, Lipsiae-Berolini 1928-1933, cetera: Oribasius, Collectiones medicae), Antyllus (Oribasius, Collectiones medicae, V, 29, 1, 1-10, 6) or Philagrius (Oribasius, Collectiones medicae, V, 17, 1, 1-11,4).

${ }^{11}$ Athenaei Naucratitae dipnosophistarum libri XV, I, 32 c-d (59, 1-17), vol. I-III, ed. G. KaIBEL, Lipsiae-Berolini 1887-1890.

${ }^{12}$ Cf. e.g. Dioscorides, Pedanii Dioscuridis Anazarbei De materia medica libri quinque, V, 6, 2, 1-5; V, 6, 3, 1-7, vol. I-III, ed. M. Wellmann, Berlin 1907-1914 (cetera: Dioscorides, De materia medica).

${ }^{13}$ More on the matter can be found in subsequent sections of the article.
} 
role, often appearing in the Holy Scriptures from the Mosaic Pentateuch in both practical commands related to worship and metaphorical descriptions of reality ${ }^{14}$. In the New Testament we find evidence of wine consumption by members of the nascent Christian community. Wine appears at the wedding at Cana (Io 3, 1-10) and during the Last Supper (Mt 26, 27-29; Lc 14, 23; Lc 22, 18-20). Relatively often it is mentioned in the letters by Saint Paul. When addressing Timothy, Saint Paul lets him drink it, but he insists that it should be consumed only for healing purposes and in small amounts (cf. 1Tim 5, 23). According to Saint Paul misuse and abuse of wine is classified as a sin and it does not allow an individual to enter the Kingdom of Heaven (Gal 5, 19-21). For this reason he encouraged Christians to refrain from drinking (Rom 14, 21).

In formulating his views on the consumption of wine, Clement focuses on related moral issues. This should come as no surprise, since he wrote his work in order to introduce the new members of the Christian community to the principles governing it.

Unlike members of Christian sects such as the Encratics ${ }^{15}$, Clement does not postulate a total ban on drinking wine ${ }^{16}$. He claims that, like water, it was created by $\mathrm{God}^{17}$. Citing the words of Saint Paul addressed to Timothy - Use some wine for stomach reasons $(1 \operatorname{Tim} 5,23)$ - he recommends that you use it with moderation ${ }^{18}$. This moderation is connected with the doctrine of the mean, which is crucial in the teaching of the Alexandrian and which was discussed in detail by Aristotle in his Nicomachean Ethics. The Stagirite describes in it ethical virtue as a disposition of will that preserves the average measure of two errors between us, that is

\footnotetext{
${ }^{14}$ T. Unwin, Wine and the Vine..., p. 66-70; D.E. Neel, J.A. Pugh, Jedzenie i uczty Jezusa. Kulinarny świat Palestyny pierwszego wieku, trans. M. KRóL, Kraków 2014, p. 43, 55-60, 118-121, 156-164; J.D. Rosenblum, Jewish Meals in Antiquity, [in:] A Companion to Food..., p. 349. Cf. D.E. Smith, Food and Dining in Early Christianity, [in:] A Companion to Food..., p. 357-364.

${ }^{15}$ The representatives of this early Christian movement rejected not only wine but meat and marriage as well: H. Chadwick, Enkrateia, [in:] RAC, vol. V, ed. T. Klauser, E. Dassmann, G. Schöllgen, Stuttgart 1962, p. 343-365; G. Quispel, The Study of Encratism. A Historical Survey, [in:] Gnostica, Judaica, Catholica. Collected Essays of Gilles Quispel, ed. J. van Oort, praef. A. DeConick, J.-P. MAhÉ, Leiden-Boston 2008 [= NHMS, 55], p. 329-363. As is clarified P. Brown (Ciało i społeczeństwo. Męzczyźni, kobiety i abstynencja seksualna we wczesnym chrześcijaństwie, trans. I. KaNIA, Kraków 2006, p. 110-111), the reason for which, next to the basic sexual abstinence, there were also dietary restrictions among the Encratics, was the fact that eating meat was considered something that binds man with wild animal carnivorousness and drinking wine was supposed to be a source of sexual energy. ${ }^{16}$ Clementis Alexandrini Paedagogus, II, II, 33, ed. M. Marcovich, J.C.M. van Winden, LeidenBoston 2002 [= VC.S, 61] (cetera: Clemens Alexandrinus, Paedagogus). Citing the description of Jesus as being "a glutton and a wine-bibber" (cf. Mt 11, 19), Clement says: Let this be held fast by us against those that are called Encratites (trans.: Clement of Alexandria, The Instructor, trans. P. Schaff, [in:] The Ante-Nicene Fathers. Translations of the Writings of the Fathers down to A.D. 325, vol. II, Fathers of the Second Century, ed. A. Roberts, J. Donaldson, New York 1913, p. 246).

${ }^{17}$ Clemens Alexandrinus, Paedagogus, II, II, 23.

${ }^{18}$ Clemens Alexandrinus, Paedagogus, II, II, 19.
} 
between excess and deprivation. This measure is defined by reason ( $\lambda$ ó $\gamma \circ \varsigma)$ and in a way in which a reasonable person would see $\mathrm{it}^{19}$. When explaining how a person should strive to achieve virtue the philosopher refers to comparing this process

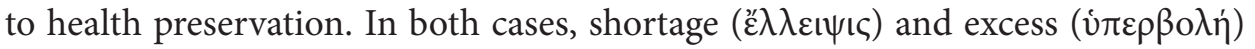
stand on the path to success. Health is destroyed both by excess and shortage of food and beverages, and maintained and strengthened when food is consumed in a proper way ${ }^{20}$.

Aristotle's doctrine of mean was very popular among his successors ${ }^{21}$. It is therefore not surprising that it also found its place in the thought of Clement ${ }^{22}$, who is known for his respect for the intellectual achievements of ancient Greeks, and who initiated the process of the synthesis of Greek philosophy with Christian teaching ${ }^{23}$.

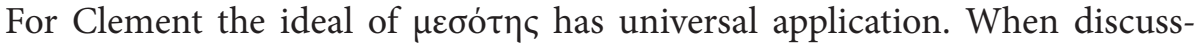
ing meal preparation, he points out that the golden mean is the basic principle in everything. While he considers extremes bad, moderation is $\operatorname{good}^{24}$. For this

${ }^{19}$ Aristotelis Ethica Nicomachea, II, 6, 1107a, ed. F. Suseminl, O. Apelt, Lipsiae 1912 [= BSGR] (cetera: Aristoteles, Ethica Nicomachea). More on Aristotle's doctrine of the golden mean: W.J. Oates, The Doctrine of the Mean, PRev 45, 1936, p. 382-398; L.W. Rosenfield, The Doctrine of the Mean in Aristotle's Rhetoric, The 31, 1965, p. 191-198; J.O. URmson, Aristotle's Doctrine of the Mean, APQ 10, 1973, p. 223-230; H.J. Curzer, A Defense of Aristotle's Doctrine that Virtue is a Mean, APhil 16, 1996, p. 129-138; R. Hursthouse, The Central Doctrine of the Mean, [in:] The Blackwell Guide to Aristotle's Nicomachean Ethics, ed. R. KraUt, Oxford 2006, p. 96-115.

${ }^{20}$ Aristoteles, Ethica Nicomachea, II, 2, 1104a.

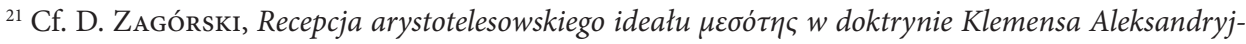
skiego. Problem definicji, RT.KUL 51, 2004, p. 10.

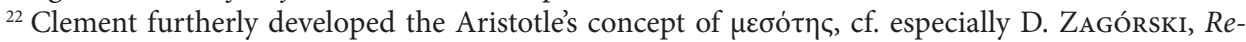

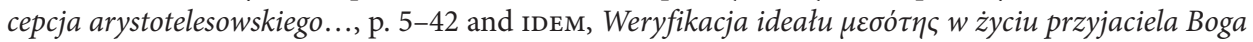

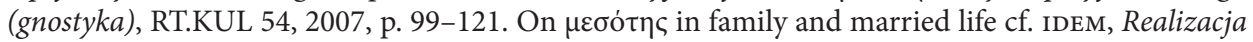

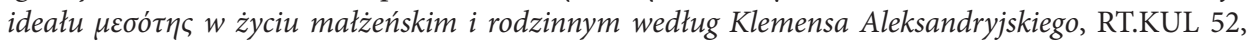
2005, p. 5-24.

${ }^{23}$ As is underlined by P. Szczur (Vetera et nova $w$ koncepcji aretologii Klemensa Aleksandryjskiego, RT.KUL 53, 2006, p. 103), one must remember that the Alexandrian took from Greek philosophy only those values which were in accord with the teachings of Christ. Due to appropriate modifications he formed the theology in statu nascendi. More about his attitude towards Hellenism and Greek philosophy, among others in: R.E. WITT, The Hellenism of Clement of Alexandria, CQ 25, 1931, p. 195-204; J.T. Muckle, Clement of Alexandria on Philosophy as a Divine Testament for the Greeks, Phoe 5, 1951, p. 79-86; J.M. SzymusiaK, Klasycyzm Klemensa Aleksandryjskiego, STV 9, 1971, p. 289-302; J. WojtczaK, Stosunek Klemensa Aleksandryjskiego do filozofii według Stromata, STV 9, 1971, p. 263-288; J. PliszczyŃsKa, Pierwsza próba syntezy filozofii greckiej z antyczna doktryna chrześcijańską. Klemensa Aleksandryjskiego, „Stromata”, E 65, 1977, p. 221-229; W. JAEGER, Wczesne chrześcijaństwo i grecka Paideia, trans. K. BIELAwski, Bydgoszcz 2001, p. 77-88; P. Szczur,

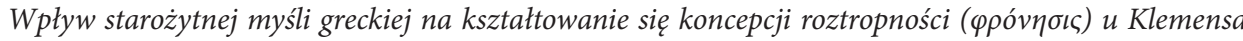
$z$ Aleksandrii, RT.KUL 50, 2003, p. 149-150; A. Heszen, „Paideia” Klemensa Aleksandryjskiego na przykładzie jego „Hymnu do Chrystusa Zbawiciela”, SPP 19, 2009, p. 121-122, 133; M. CZARNuCH, Clement of Alexandria's Attitude towards the Greek Philosophy, SCl 10, 2013, p. 141-146.

${ }^{24}$ Clemens Alexandrinus, Paedagogus, II, I, 16. 
reason, he recommends that you always watch the right measure. In relation to food, it boils down to avoiding both delicacies and an overly strict diet. Thus, the right diet is between the two extremes, on the one hand it is free from luxury and on the other hand from excessive restrictions ${ }^{25}$. The essence of $\mu \varepsilon \sigma o$ tr $\varsigma$ is the aforementioned moderation, which Clement often emphasizes ${ }^{26}$. In his opinion, the loss of restraint, which is disastrous for a Christian, can be observed especially in relation to food ${ }^{27}$. Clement warns against treating food as a source of pleasure, because, although everything was created for people, one should not use everything. One should avoid life dependent on the stomach ${ }^{28}$. Exactly the same principle as the one shown in Paedagogus can be applied to drinking wine.

To quote a fragment from Sirach's Wisdom - wine drunk in season and temperately is rejoicing of heart and gladness of soul (Eccli 31,28). The Alexandrian acknowledges that it is best to mix wine with water to weaken its strength. At the same time, he insists on not overdoing it and not diluting wine excessively. Clement stresses that both are works of God; and so the mixture of both, of water and of wine, conduces together to health, because life consists of what is necessary and of what is useful ${ }^{29}$. The custom of mixing wine with water has a long tradition in the Greek-Roman world, in which it was perceived as one of staples of civilization, distinguishing the Greeks and Romans from the barbarians. Clement supports this claim and cites Plato who states that the Celts, Iberians and Thracians are prone to drunkenness particularly often. The Alexandrian adds that in contrast to peace-oriented Greeks, who during feasts maintain moderation and stay sober, barbarians are militant people ${ }^{30}$.

Clement recommends, therefore, to satisfy thirst with moderation and not to be valiant over wine, for wine has destroyed many (cf. Eccli 31, 25) ${ }^{31}$. Christ himself can be considered as the best model in this regard. He drank wine with moderation and prudence, maintaining dignity, and Clement believes that Christ additionally taught during feasts and showed how those consuming wine should show restraint ${ }^{32}$.

Abuse of wine leads to behaviors that the Alexandrian criticizes with full severity. To increase this effect, he resorts to detailed descriptions of the condition of those who did not adhere to the ideal principle $\mu \varepsilon \sigma o$ ó $\eta \varsigma$ and let themselves be carried away by the excesses of drunkenness. Wine that has not been mixed

\footnotetext{
${ }^{25}$ Clemens Alexandrinus, Paedagogus, III, X, 51.

${ }^{26}$ E.g. Clemens Alexandrinus, Paedagogus, I, XII, 99.

${ }^{27}$ Clemens Alexandrinus, Paedagogus, II, I, 11.

${ }^{28}$ Clemens Alexandrinus, Paedagogus, II, I, 14.

${ }^{29}$ Clemens Alexandrinus, Paedagogus, II, II, 23 (trans.: Clement of Alexandria, The Instructor..., p. 243).

${ }^{30}$ Clemens Alexandrinus, Paedagogus, II, II, 32.

${ }^{31}$ Clemens Alexandrinus, Paedagogus, II, II, 31.

${ }^{32}$ Clemens Alexandrinus, Paedagogus, II, II, 32.
} 
with water consumed in excess twists tongues, causes the lip to fall, disrupts the eyes, resulting in the eyes to seem as if they were swimming submerged in water. A drunk man is not able to properly perceive reality and see anything from afar, but he thinks that everything revolves around him and things multiply in front of his eyes. To this end, hiccups and vomiting tire him ${ }^{33}$. Under the influence of drunkenness one is prone to contradicting states - croaking and crying ${ }^{34}$. In turn, half-drunk men walk with an uncertain step, have wreaths around their necks like vats, and spit at each other with wine. Others suffer from headaches, they are dirty, pale and blue on their faces, but they are still looking for opportunities to drink. Such an image is considered by Clement as ridiculous and worthy of compassion, and he perceives those who have fallen to drunkenness as a spectacle and laughing stock ${ }^{35}$. Clement uses two Old Testament characters - Noe and Lot - as examples of drunkards. The negative effects of their misuse of wine are presented as a warning against such behavior of others ${ }^{36}$.

The state of drunkenness affects not only men but also young people and women. According to our author, young boys and girls should avoid this poison, i.e. wine, since it has a disastrous effect on their bodies. As Clement states: For hence wild impulses and burning lusts and fiery habits are kindled; and young men inflamed from within become prone to the indulgence of vicious propensities; so that signs of injury appear in their body, the members of lust coming to maturity sooner than they ought. This leads them directly to behave in a shameful way ${ }^{37}$. As per women, Clement mocks their allegedly sophisticated way in which they open their mouths and tilt their heads while drinking. A drunk woman, according to the biblical passages that he quotes, should be condemned since her behavior brings God's wrath. Such a woman is seen to be great evil. Clement however does not ban women from using wine since in his opinion a woman with an innate sense of shame will not misbehave or behave noisily while drinking ${ }^{38}$.

Clement compares drunkenness to poison again, stating that it also brings death to men ${ }^{39}$. The only way of avoiding it is relying on the previously mentioned reason (logos), which will make it possible to determine the right measure in the consumption of this drink. The Alexandrian recommends, figuratively, to invite logos to feasts, to control the drinking of wine and not to go down the path

\footnotetext{
${ }^{33}$ Clemens Alexandrinus, Paedagogus, II, II, 24.

${ }^{34}$ Clemens Alexandrinus, Paedagogus, II, VII, 56.

${ }^{35}$ Clemens Alexandrinus, Paedagogus, II, II, 26.

${ }^{36}$ Clemens Alexandrinus, Paedagogus, II, II, 34; II, IX, 81.

${ }^{37}$ Clemens Alexandrinus, Paedagogus, II, II, 20 (trans.: Clement of Alexandria, The Instructor..., p. 243).

${ }^{38}$ Clemens Alexandrinus, Paedagogus, II, II, 33. Cf. P. Wygralak, Vinum laetificat cor hominis (Ps 104, 15). Ojcowie Kościoła o spożywaniu wina i związanych z tym problemach, PST 25, 2011, p. 150. ${ }^{39}$ Clemens Alexandrinus, Paedagogus, II, VII, 56, cf. II, II, 27.
} 
of drunkenness. When drinking, you should know when to stop and postpone serious matters until the morning ${ }^{40}$. Reason is necessary for the consumption of wine also because in people prone to drunkenness, as our author expresses it metaphorically, the center of thinking is not in the head but in the guts - the brain occupies the place of the liver and heart, and thus goes where the center of pleasure and anger is located. This makes one enslaved by passions, lusts and anger ${ }^{41}$. Presenting the issue that interests us, Clement goes back to comparing the condition of a person drinking wine in excess to a sinking ship in rough waters. The immensity of drunkenness is depicted here as a dangerous sea in which the human body sinks like a ship flooded with waves. The captain, which is the human mind, staggers in a state of intoxication and cannot reach the port during the storm. Thrown on the rocks, he eventually destroys himself, stranded ${ }^{42}$.

According to Clement, pure water, which God gave Jews as a healthy and natural drink, satisfies thirst naturally. It was water which was the original drink of man - the vine appeared later ${ }^{43}$. Compliance with Clement's recommendations for drinking wine, which, in short, come down to respecting the principle $\mu \varepsilon \sigma o$ $\tau \eta \varsigma$, and therefore the principles of the golden mean and above all the principle of rational moderation, allows Christians to safely reach for this drink. The Alexandrian supports his recommendations in this respect with the authority of Saint Paul and the Paedagogus himself, meaning Christ, who do not prohibit drinking wine, but only overusing for $\mathrm{it}^{44}$. He advises, however, that in order to satisfy one's desire one should avoid brand wines. Their task will be fulfilled by outstanding local drinks, not imported ones, and this is because for the ordinary user every wine is the same, because they are all a gift of $\mathrm{God}^{45}$. Interestingly, Clement also instructs his readers as to what the activity of drinking wine should look like. His advice, in short, boils down to behaving in an elegant manner ${ }^{46}$.

Satisfying thirst is not, however, in our author's opinion, the only function that wine can fulfill. We must emphasize strongly that he also ascribes it a positive influence on individual, social and family spheres of human life, stating that wine primarily makes the drinker well-disposed towards himself, pleasant to friends, polite towards his companions and more gentle to his family members ${ }^{47}$.

As we have already mentioned, Clement in his views on the consumption of wine by Christians is far from the rigor of the Encratics, whose representative,

\footnotetext{
${ }^{40}$ Clemens Alexandrinus, Paedagogus, II, II, 25.

${ }^{41}$ Clemens Alexandrinus, Paedagogus, II, II, 34.

${ }^{42}$ Clemens Alexandrinus, Paedagogus, II, II, 28.

${ }^{43}$ Clemens Alexandrinus, Paedagogus, II, II, 19.

${ }^{44}$ Clemens Alexandrinus, Paedagogus, II, II, 28; II, II, 29.

${ }^{45}$ Clemens Alexandrinus, Paedagogus, II, II, 30.

${ }^{46}$ Clemens Alexandrinus, Paedagogus, II, II, 31; II, II, 33.

${ }^{47}$ Clemens Alexandrinus, Paedagogus, II, II, 23.
} 
Tatian the Assyrian (around 130 - c. 193), rejected it completely ${ }^{48}$. Born two centuries after Clement, John Chrysostom, bishop of Constantinople (before 350-407), whom we can definitely consider one of the most outstanding representatives of ancient social thought ${ }^{49}$, in his sermons and homilies often discussed the subject of drinking wine ${ }^{50}$. Like Clement, only with much greater enthusiasm and with the use of a whole range of rhetorical resources, he criticized its misuse. $\mathrm{He}$ saw drunkenness as a serious offense, the cause and source of many faults and sins $^{51}$. Alcohol abuse was perceived not only as a disease that a drunk person put on himself ${ }^{52}$, but also as a way of destroying the local community ${ }^{53}$. One of wine's main negative effects was, according to Chrysostom, that it ruined the spiritual life of a man and deprived him of all the benefits he could have from the virtues that were not easy to achieve ${ }^{54}$. Similarly to Clement, John believed that over-consumption of alcohol easily contributed to the unrighteousness of sexual impurity, i.e. adultery ${ }^{55}$. The weight of sin, which was drunkenness, was so great that in his opinion it completely deprived man of a chance to enter the Kingdom of $\operatorname{God}^{56}$. John mainly warned the elder people about excessive consumption of wine, and in order to discourage his listeners from abusing alcohol ${ }^{57}$, he provided them (to a much greater extent than Clement) with vivid descriptions of drunkards ${ }^{58}$. It seems that in view of such a strict assessment of the consequences of the behavior of those who undergo excessive consumption of the drink in question, the Bishop, in contrast to Clement, would hardly find any positive influence of drinking wine on a person - whether individual, social or having to do with family life.

\footnotetext{
${ }^{48}$ As W.L. Petersen (Tatian the Assyrian, [in:] A Companion to Second-Century Christian "Heretics", ed. A. Marjanen, P. Luomanen, Leiden-Boston 2005 [= VC.S, 76], p. 142) points out, the idea that Tatian was a teetotaler first appears in Jerome (c. 385), but whether his tradition is reliable, or whether he simply inherited it from earlier descriptions of Encratism, remains unknown.

${ }^{49}$ P. Szczur, Problematyka społeczna w późnoantycznej Antiochii. Na podstawie nauczania homiletycznego Jana Chryzostoma, Lublin 2008, passim.

${ }^{50}$ Cf. P. Wygralak, Vinum laetificat..., passim; P. Szczur, Problematyka społeczna..., p. 440-454; IDEM, John Chrysostom's Assessment of Drunkenness, VP 33, 2013, p. 387-400.

${ }^{51}$ P. Szczur (John Chrysostom's Assessment..., p. 387-388), on the ground of numerous statements of the bishop, determines how he defined the abuse of alcohol.

${ }^{52}$ Joannes Chrysostomus, Adversus Judaeos, or. 8, 1, PG, vol. XLVIII, col. 928; Ad populum Antiochenum, hom. 1, 5, PG, vol. XLIX, col. 22.

${ }^{53}$ JoAnnes Chrysostomus, Ad populum Antiochenum, hom. 1, 5, PG, vol. XLIX, col. 22. Cf. P. Szczur, John Chrysostom's Assessment..., p. 394-395.

${ }^{54}$ Joannes Chrysostomus, In Matthaeum, hom. 57, 5, PG, vol. LVIII, col. 566.

${ }^{55}$ Joannes Chrysostomus, In Matthaeum, hom. 57, 5, PG, vol. LVIII, col. 564; In epistulam ad Romanos, hom. 24, 3, PG, vol. LX, col. 626.

${ }^{56}$ Joannes Chrysostomus, In Matthaeum, hom. 57, 5, PG, vol. LVIII, col. 566; Ad populum Antiochenum, hom. 1, 5, PG, vol. XLIX, col. 22; Adversus ebriosos et de resurrectione Domini nostri Iesu Christi, 1, PG, vol. L, col. 435.

${ }^{57}$ Joannes Chrysostomus, In epistulam ad Titum, hom. 4, 1, PG, vol. LXII, col. 683.

${ }^{58}$ E.g. Joannes Chrysostomus, Adversus Judaeos, or. 8, 1, PG, vol. XLVIII, col. 928; In epistulam ad Romanos, hom. 13, 11, PG, vol. LX, col. 522.
} 
Just as Clement also Chrysostom (being in harmony with the biblical teaching) considered wine to be God's gift and as such he treated it not as something bad, but as something good ${ }^{59}$. It is wine abusing that is $\mathrm{bad}^{60}$. The bishop allowed it to be consumed, but he emphasized that it should be done with moderation ${ }^{61}$. Referring to the words of Saint Paul addressed to Timothy (cf. 1Tim 5, 23), he underlined that the apostle's consent to drinking a little wine resulted only from the fact that Timothy was not feeling well and wine was supposed to act as a medicine ${ }^{62}$.

Thus, although both authors - John and Clement - remain strongly negative about the abuse of wine, the first of these expresses his reasons more clearly. The reason for this are undoubtedly his rhetorical skills and the fact that he speaks to the faithful, and does not write down his teachings, which could cool the heat of his statements. Perhaps, however, the reason for this difference in the intensity of criticism is also that each of them directed their words to a different audience and John had more opportunities to see the effects of the brainless drunkenness of Christians, whom he led as a spiritual and moral authority.

The Alexandrian is known for his comprehensive knowledge of medicine and ancient medical treaties ${ }^{63}$. We find evidence for this in all of his work, including the analyzed Paedagogus. Unfortunately, his statements about wine provide us with only a few references to the ways of using this drink as a medicine. We will quote them here, trying to confront them with the teachings of two ancient Greek medical writers, Pedanius Dioscorides (c. 40 - 90 AD), a physician, pharmacologist and botanist, and Galen of Pergamon (129 AD - c. 200/c. 216), a physician, surgeon and philosopher. Above all, Clement recommends sensible use of wine for those who want to avoid the chills that affect them due to the cold, especially if they are susceptible to them ${ }^{64}$. He also recommends it to the elderly, as a medicine, also for warming up ${ }^{65}$. These words correspond to both Galen's words,

\footnotetext{
${ }^{59}$ Joannes Chrysostomus, In Matthaeum, hom. 57, 5, PG, vol. LVIII, col. 564.

${ }^{60}$ Joannes Chrysostomus, Ad populum Antiochenum, hom. 1, 4, PG, vol. XLIX, col. 22; Ad populum Antiochenum, hom. 2, 5, PG, vol. XLIX, col. 40; In Matthaeum, hom. 57, 5, PG, vol. LVIII, col. 564. ${ }^{61}$ Joannes Chrysostomus, Adversus ebriosos et de resurrectione Domini nostri Iesu Christi, 1, PG, vol. L, col. 433.

${ }^{62}$ Joannes Chrysostomus, Ad populum Antiochenum, hom. 1, 5, PG, vol. XLIX, col. 22-23.

${ }^{63}$ J.M. Szymusiak, Klasycyzm Klemensa..., p. 293; M. Koкoszкo, J. Dyвa£A, K. Jagusiak, Z. RzeźNICKA, Chleb nieodpowiedni dla chrześcijan: moralne zalecenia Klemensa Aleksandryjskiego w konfrontacji z naukowymi ustaleniami Galena, VP 35, 2015, p. 258.

${ }^{64}$ Clemens Alexandrinus, Paedagogus, II, II, 29.

${ }^{65}$ Clemens Alexandrinus, Paedagogus, II, II, 22. On wine heating by the Romans during the winter time cf. M. Koкoszko, Smaki Konstantynopola, [in:] Konstantynopol - Nowy Rzym. Miasto i ludzie w okresie wczesnobizantyńskim, ed. M.J. LeszKa, T. WolińsKa, Warszawa 2011, p. 565. John Chrysostom (JoAnnes Chrysostomus, In epistulam I ad Timotheum, hom. 13, 4, PG, vol. LXII, col. 569) argued that wine is mainly abused by older women who need warming up because of episodes of chills in the elderly. He banned them from excessive wine drinking because it resulted in indecent laughter. The women could consume wine in small amounts in order to warm up their
} 
who states that old people should drink wine because their bodies are cool and wine has warming qualities ${ }^{66}$, as well as to the words of Dioscorides ${ }^{67}$, according to whom dry wine which is undiluted by water is warming. Additionally, as we read in the works of the second of the above-mentioned experts in his contemporary medical art, it is also advisable to drink wine with the addition of tar or pine resin to warm up ${ }^{68}$.

Another situation in which Clement recommends the consumption of wine for medical reasons is when one has digestive problems. Soft and sweet wine, mixed in proper proportions with water ${ }^{69}$ is supposed to alleviate those problems. However, Dioscorides claimed that - on the contrary - sweet wine causes digestive problems, disrupting the functioning of the gastrointestinal $\operatorname{tract}^{70}$. In addition, the Alexandrian believed that wine prevents unpleasant odors ${ }^{71}$. If what he was referring to were gases produced by the organism, his words would once again be in contradiction to the opinion expressed by Dioscorides, who claimed that such liquor fills the stomach with gases ${ }^{72}$. It is also worth referring to the Alexandrian's opinion we have already presented regarding the pernicious effects of drinking wine by young people. Galen states that he knew many who often drunk black and tart wine, and that these not only did not harm their bodies, but were nutritious and helped to keep them in good physical shape. One should drink such wines in moderation, not to hurt oneself $\mathrm{f}^{73}$. Elsewhere ${ }^{74}$, however, Galen's argument remains essentially in line with the words of Clement, because the Pergamon writes that young people should avoid wine. This was due to the fact that it is a warming drink, and the constitution of young organisms is hot in itself, so they should not be additionally warmed up ${ }^{75}$. With this we reach the end of Clement's

bodies, cf. J. DyваŁA, Ideał kobiety w pismach kapadockich Ojców Kościoła i Jana Chryzostoma, Łódź 2012 [= BL, 14], p. 119-120.

${ }^{66}$ Galeni De sanitate tuenda, 334, 5-6, vol. VI, ed. K. Косн, [in:] Galeni De sanitate tuenda, De alimentorum facultatibus, De bonis malisque sucis, De victu attenuante, De ptisana, ed. K. KocH, G. Halmreich, K. Kalbfleisch, O. Hartlich, Lipsiae-Berolini 1923 (cetera: Galenus, De sanitate tuenda).

${ }^{67}$ Dioscorides, De materia medica, V, $6,10,1-11,1$.

${ }^{68}$ Dioscorides, De materia medica, V, 6, 5, 6-8.

${ }^{69}$ Clemens Alexandrinus, Paedagogus, II, II, 29; II, II, 23.

${ }^{70}$ Dioscorides, De materia medica, 6, 2, 6-9.

${ }^{71}$ Clemens Alexandrinus, Paedagogus, II, II, 23.

${ }^{72}$ Dioscorides, De materia medica, V, 6, 2, 6-9.

${ }^{73}$ Galeni De victu attenuante, 102, 1 - 103, 3, ed. C. Kalbfleisch, [in:] Galeni De sanitate tuenda, De alimentorum...

${ }^{74}$ Galenus, De sanitate tuenda, 335, 12 , vol. VI.

${ }^{75}$ Galenus, De sanitate tuenda, 334, 5-6, vol. VI. The Aretaeus of Cappadocia, a Greek physician, who most likely lived around the $1^{\text {st }}$ century $\mathrm{AD}$ also wrote about wine as a source of sexual energy (AREtaeus, De curatione acutorum morborum libri duo, [in:] The Extant Works of Aretaeus the Cappadocian, ed. et trans. F. Adams, London 1856). Cf. V.E. Grimm, From Feasting to Fasting. The Evolution of a Sin. Attitudes to Food in Late Antiquity, London 1996, p. 101-102. 
advice on the use of wine as a medicinal product. We can say that in this matter he showed some knowledge of professional views, although we do not find here any knowledge reaching deeper than, probably, what was commonly known.

At this point, it is worth referring to Clement's statement that young, sweet wine breaks all barriers of shame. According to Dioscorides ${ }^{76}$ sweet wine cannot be drunk as quickly as dry wine, and young wines are less tasty than ripe ones ${ }^{77}$. It seems, therefore, that people familiar with the findings of late-ancient medicine and recognizing them as correct, would not be afraid of young and sweet wine. It must be admitted, however, that Clement's words seem to hold true with regards to how they correspond to the obvious human predilection for sweet taste in general, including sweet drinks.

The final element which would complete the Alexandrian's views on wine is ancient culinary arts. Here, unfortunately, we must conclude Paedagogus is a poor source of information. The input in this respect is limited to enumerating several names of imported wines whose consumption the author advises against - for moral reasons. What is interesting, however, is the fact that he knows these type of wines, which makes him a kind of an antique sommelier.

The vast majority of Titus Flavius Clemens' statements about wine and its consumption is connected with moral recommendations, which he formulated in relation to this beverage when addressing the Alexandrian Christian community. This should not be surprising, because the main purpose of his Paedagogus was to instill in the followers of the new faith the right virtues and appropriate behavior. Clement's teaching is consistent with what we know about wine from the Bible, and especially from the New Testament. As a drink created by God, it cannot be rejected by Christians - only heretics do so. The main principle that applies to its consumption is the need to maintain moderation. This principle perfectly fits with the ideal of $\mu \varepsilon \sigma o ́ \tau \eta \varsigma$ appreciated by the Alexandrian. Clement's ethical views on wine drinking do not differ from those expressed later on by the bishop of Constantinople, John Chrysostom.

As per wine's medical and culinary values, Paedagogus cannot be considered as a rich source of information. Knowledge about how to consume wine in order to help and not harm your health turns out to be very superficial. Based on Paedagogus we know that Clement knew various medical theories, but we find no traces of them in the fragments related to wine drinking. On the contrary, one may be under the impression that Clement only described what was commonly known. When it comes to wine understood as a beverage to accompany meals, Clement does not list more than just a few types in Paedagogus.

\footnotetext{
${ }^{76}$ Dioscorides, De materia medica, V, 6, 2, 6-9.

${ }^{77}$ Dioscorides, De materia medica, V, 6, 1, 1-7.
} 


\section{Bibliography}

\section{Primary Sources}

Aretaeus, De curatione acutorum morborum libri duo, [in:] The Extant Works of Aretaeus the Cappadocian, ed. et trans. F. AdAms, London 1856.

Aristotelis Ethica Nicomachea, ed. F. Suseminl, O. Apelt, Lipsiae 1912 [= Bibliotheca Scriptorum Graecorum et Romanorum Teubneriana].

Athenaei Naucratitae dipnosophistarum libri XV, vol. I-III, ed. G. KAIBEL, Lipsiae-Berolini 1887-1890.

Clementis Alexandrini Paedagogus, ed. M. Marcovich, J.C.M. van Winden, Leiden-Boston 2002 [= Supplements to Vigiliae Christianae, 61]. Translation: Clement of Alexandria, The Instructor, trans. P. Schaff, [in:] The Ante-Nicene Fathers. Translations of the Writings of the Fathers down to A.D. 325, vol. II, Fathers of the Second Century, ed. A. Roberts, J. Donaldson, New York 1913, p. 207-298.

Galeni De sanitate tuenda, ed. K. Косн, [in:] Galeni De sanitate tuenda, De alimentorum facultatibus, De bonis malisque sucis, De victu attenuante, De ptisana, ed. K. Косн, G. Нalmreich, K. KalbFLEISCH, O. HARTLICH, Lipsiae-Berolini 1923.

Galeni De victu attenuante, ed. C. Kalbfleisch, [in:] Galeni De sanitate tuenda, De alimentorum facultatibus, De bonis malisque sucis, De victu attenuante, De ptisana, ed. K. КосH, G. Halmreich, K. Kalbfleisch, O. Hartlich, Lipsiae-Berolini 1923.

Joannes Chrysostomus, Ad populum Antiochenum, hom. 1, [in:] Patrologiae cursus completus, Series graeca, vol. XLIX, ed. J.-P. Migne, Paris 1862, col. 15-34.

Joannes Chrysostomus, Ad populum Antiochenum, hom. 2, [in:] Patrologiae cursus completus, Series graeca, vol. XLIX, ed. J.-P. Migne, Paris 1862, col. 34-48.

Joannes Chrysostomus, Adversus ebriosos et de resurrectione Domini nostri Iesu Christi, [in:] Patrologiae cursus completus, Series graeca, vol. L, ed. J.-P. Migne, Paris 1862, col. 433-442.

Joannes Chrysostomus, Adversus Judaeos, or. 8, [in:] Patrologiae cursus completus, Series graeca, vol. XLVIII, ed. J.-P. Migne, Paris 1862, col. 928-942.

Joannes Chrysostomus, In epistulam ad Romanos, hom. 13, [in:] Patrologiae cursus completus, Series graeca, vol. LX, ed. J.-P. Migne, Paris 1862, col. 507-524.

Joannes Chrysostomus, In epistulam ad Romanos, hom. 24, [in:] Patrologiae cursus completus, Series graeca, vol. LX, ed. J.-P. Migne, Paris 1862, col. 622-628.

Johnnes Chrysostomus, In epistulam ad Titum, hom. 4, [in:] Patrologiae cursus completus, Series graeca, vol. LXII, ed. J.-P. Migne, Paris 1862, col. 682-688.

Joannes Chrysostomus, In epistulam I ad Timotheum, hom. 13, [in:] Patrologiae cursus completus, Series graeca, vol. LXII, ed. J.-P. Migne, Paris 1862, col. 564-572.

Joannes Chrysostomus, In Matthaeum, hom. 57, [in:] Patrologiae cursus completus, Series graeca, vol. LVIII, ed. J.-P. Migne, Paris 1862, col. 557-566.

Oribasii collectionum medicarum reliquiae, vol. I-IV, ed. I. RAEDER, Lipsiae-Berolini 1928-1933.

Pedanii Dioscuridis Anazarbei De materia medica libri quinque, vol. I-III, ed. M. Wellmann, Berlin 1907-1914. 


\section{Secondary Literature}

Alessi R., Le vin dans les Épidémies d'Hippocrate, [in:] Vin et santé en Grèce Ancienne. Actes du Colloque organisé à l'Université de Rouen et à Paris, 28-30 septembre 1998, ed. J. Jounanna, L. Villard, Athènes 2002, p. 105-112.

Altaner B., Stuiber B., Patrologia, trans. P. Pachciarek, Warszawa 1990.

Ashwin-Siejkowski P., Clement of Alexandria. A Project of Christian Perfection, London 2008.

BÉGUIN D., Le vin médecin chez Galien, [in:] Vin et santé en Grèce Ancienne. Actes du Colloque organisé à l'Université de Rouen et à Paris, 28-30 septembre 1998, ed. J. Jounanna, L. Villard, Athènes 2002, p. 141-154.

Boulay T., Wine Appreciation in Ancient Greece, [in:] A Companion to Food in the Ancient World, ed. J. Wilkins, R. NAdEAU, Malden-Oxford 2015, p. 271-282.

Broekaert W., Zuiderhoek A., Food Systems in Classical Antiquity, [in:] A Cultural History of Food in Antiquity, ed. P. Erdkamp, London-New York 2016, p. 41-55.

Brown P., Ciało i społeczeństwo. Mężczyźni, kobiety i abstynencja seksualna we wczesnym chrześcijaństwie, trans. I. Kania, Kraków 2006.

Campenhausen H. von, Ojcowie Kościoła, trans. K. WierszyŁowski, Warszawa 1998.

Chadwick H., Enkrateia, [in:] Reallexikon für Antike und Christentum, vol. V, ed. T. Klauser, E. Dassmann, G. Schöllgen, Stuttgart 1962, p. 343-365.

Corner S., Symposium, [in:] A Companion to Food in the Ancient World, ed. J. Wilkins, R. NAdeau, Malden-Oxford 2015, p. 234-242.

Curzer H.J., A Defense of Aristotle's Doctrine that Virtue is a Mean, "Ancient Philosophy" 16, 1996, p. $129-138$.

Czarnuch M., Clement of Alexandria's Attitude towards the Greek Philosophy, "Scripta Classica" 10, 2013, p. 141-146.

Dalby A., Food in Antiquity from A to Z, London-New York 2003.

DyваєA J., Ideał kobiety w pismach kapadockich Ojców Kościoła i Jana Chryzostoma, Łódź 2012 [= Byzantina Lodziensia, 14].

Fisher N.R.E., Drink, Hybris and the Promotion of Harmony in Sparta, [in:] Classical Sparta. Techniques behind Her Success, ed. A. Powell, London 1989, p. 26-50.

Grace V.R., Amphoras and the Ancient Wine Trade, Princeton 1979.

Grimm V.E., From Feasting to Fasting. The Evolution of a Sin. Attitudes to Food in Late Antiquity, London 1996.

Halstead P., Food Production, [in:] A Cultural History of Food in Antiquity, ed. P. Erdkamp, London-New York 2016, p. 21-39.

Heszen A., „Paideia” Klemensa Aleksandryjskiego na przykładzie jego „Hymnu do Chrystusa Zbawiciela", "Symbolae Philologorum Posnaniensium" 19, 2009, p. 121-134.

Hursthouse R., The Central Doctrine of the Mean, [in:] The Blackwell Guide to Aristotle's Nicomachean Ethics, ed. R. Kraut, Oxford 2006, p. 96-115.

Jaeger W., Wczesne chrześcijaństwo i grecka Paideia, trans. K. Bielawski, Bydgoszcz 2001.

JAGUSIAK K., Zastosowania buraka (Beta vulgaris L.) w sztuce medycznej grecko-rzymskiego antyku i wczesnego Bizancjum (II-VII w.), [in:] Lek roślinny, vol. IV, ed. B. PŁonka-Syroka, A. Syroka, Wrocław 2015, p. 35-48. 
KACZOR I., Deus - ritus - cultus. Studium na temat charakteru religii starożytnych Rzymian, Łódź 2012.

Karavites P., Evil - Freedom - and the Road to Perfection in Clement of Alexandria, Leiden-Boston-Köln 1999.

Кокозzко M., Enologia Dioskuridesa, czyli kilka uwag na temat leczniczego działania wina, [in:] Historia panaceum. Między marzeniem a oszustwem, ed. W. Korpalska, W. ŚLusarczyK, Bydgoszcz 2016, p. 49-62.

Kокоszко M., Smaki Konstantynopola, [in:] Konstantynopol - Nowy Rzym. Miasto i ludzie w okresie wczesnobizantyńskim, ed. M.J. LeszKa, T. WolińsKa, Warszawa 2011, p. 471-575.

Кокоszко M., JAGUsiak K., Woda, wino i tak dalej, czyli o napojach i trunkach w Konstantynopolu, "Przegląd Nauk Historycznych" 9, 1, 2010, p. 25-54.

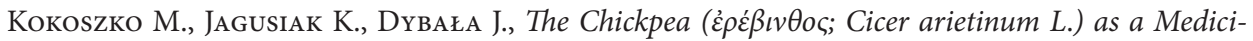
nal Foodstuff and Medicine in Selected Greek Medical Writings, "Studia Ceranea. Journal of the Waldemar Ceran Research Center for the History and Culture of the Mediterranean Area and South-Eastern Europe" 7, 2017, p. 99-120.

Koкoszko M., Dybaєa J., Jagusiak K., Rzeźnicka Z., Chleb nieodpowiedni dla chrześcijan: moralne zalecenia Klemensa Aleksandryjskiego w konfrontacji z naukowymi ustaleniami Galena, "Vox Patrum. Antyk Chrześcijański” 35, 2015, p. 249-291.

Kowalewska M., Szczur P., Klemens Aleksandryjski, [in:] Powszechna Encyklopedia Filozofii, vol. V, ed. A. KrąPiec, A. Maryniarczyk, P. Jaroszyński, Lublin 2004, p. 637-641.

Muckle J.T., Clement of Alexandria on Philosophy as a Divine Testament for the Greeks, "Phoenix. Journal of the Classical Association of Canada / Revue de la Société canadienne des études classiques" 5, 1951, p. 79-86.

Naumowicz J., Wstęp, [in:] Klemens Aleksandryjski, Który człowiek bogaty może być zbawiony?, trans. J. Czuj, ed. J. Naumowicz / Pseudo-Klemens, Zachęta do wytrwałości, trans. et ed. J. Naumowicz, Kraków-Ząbki 1995, p. 5-32.

Neel D.E., Pugh J.A., Jedzenie i uczty Jezusa. Kulinarny świat Palestyny pierwszego wieku, trans. M. KRóL, Kraków 2014.

Nevett L., Domestic Space in Classical Antiquity, Cambridge 2010.

Niemirska-Pliszczyńska J., Wstęp, [in:] Klemens Aleksandryjski, Kobierce zapisków filozoficznych dotyczących prawdziwej wiedzy, vol. I, trans. et ed. J. Niemirska-PliszczyŃska, Warszawa 1994, p. VII-XI.

OAtes W.J., The Doctrine of the Mean, "Philosophical Review" 45, 1936, p. 382-398.

Osborn E., Clement of Alexandria, Cambridge 2005.

Petersen W.L., Tatian the Assyrian, [in:] A Companion to Second-Century Christian "Heretics", ed. A. Marjanen, P. Luomanen, Leiden-Boston 2005 [= Supplements to Vigiliae Christianae, 76], p. 125-158.

Pliszczyńska J., Pierwsza próba syntezy filozofii greckiej z antyczna doktryną chrześcijańską. Klemensa Aleksandryjskiego „Stromata", "Eos. Commentarii Societatis Philologae Polonorum” 65, 1977, p. 221-229.

Purcell N., Wine and Wealth in Ancient Italy, "Journal of Roman Studies" 75, 1985, p. 1-19.

Quispel G., The Study of Encratism. A Historical Survey, [in:] Gnostica, Judaica, Catholica. Collected Essays of Gilles Quispel, ed. J. van OorT, praef. A. DeConick, J.-P. MahÉ, Leiden-Boston 2008 [= Nag Hammadi and Manichaean Studies, 55], p. 329-363. 
Rosenblum J.D., Jewish Meals in Antiquity, [in:] A Companion to Food in the Ancient World, ed. J. Wilkins, R. Nadeau, Malden-Oxford 2015, p. 348-356.

Rosenfield L.W., The Doctrine of the Mean in Aristotle's Rhetoric, "Theoria: A Swedish Journal of Philosophy and Psychology" 31, 1965, p. 191-198.

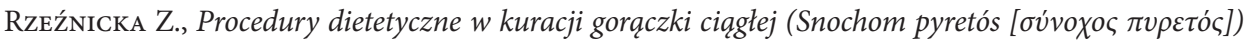
na podstawie wybranych traktatów medycznych antyku i Bizancjum, [in:] Historia diety i kultury odżywiania, vol. I, ed. B. PŁonka-Syroka, H. Grajeta, A. Syroka, Wrocław 2018, p. 43-55.

Rzeźnicka Z., Koкоszко M., Czosnek w medycynie wczesnego Bizancjum na przykładzie pism Orybazjusza, [in:] Lek roślinny, vol. IV, ed. B. PŁonka-Syroka, A. Syroka, Wrocław 2015, p. 49-61.

SEAley P.R., New Light on the Wine Trade with Julio-Claudian Britain, "Britannia: A Journal of Romano-British and Kindred Studies" 40, 2009, p. 1-40.

Sмiтн D.E., Food and Dining in Early Christianity, [in:] A Companion to Food in the Ancient World, ed. J. Wilkins, R. NADEAU, Malden-Oxford 2015, p. 357-364.

Szarmach M., Wstęp, [in:] Klemens Aleksandryjski, Wychowawca, trans. et ed. M. Szarmach, Toruń 2012, p. 7-11.

Szczur P., John Chrysostom's Assessment of Drunkenness, "Vox Patrum. Antyk Chrześcijański” 33, 2013, p. 387-400.

Szczur P., Problematyka społeczna w późnoantycznej Antiochii. Na podstawie nauczania homiletycznego Jana Chryzostoma, Lublin 2008.

Szczur P., Vetera et nova w koncepcji aretologii Klemensa Aleksandryjskiego, "Roczniki Teologiczne Katolickiego Uniwersytetu Lubelskiego" 53, 2006, p. 87-105.

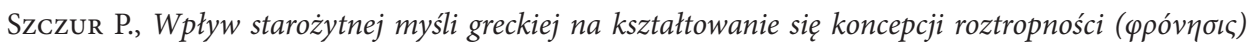
u Klemensa $z$ Aleksandrii, "Roczniki Teologiczne Katolickiego Uniwersytetu Lubelskiego" 50, 2003, p. 149-170.

Szymusiak J.M., Klasycyzm Klemensa Aleksandryjskiego, "Studia Theologica Varsaviensia" 9, 1971, p. 289-302.

Thurmond D.L., From Vines to Wines in Classical Rome. A Handbook of Viticulture and Oenology in Rome and the Roman West, Leiden-Boston 2017.

Unwin T., Wine and the Vine. An Historical Geography of Viticulture and the Wine Trade, LondonNew York 1996.

Urmson J.O., Aristotle's Doctrine of the Mean, "American Philosophical Quarterly" 10, 1973, p. 223-230.

Vidal Manzanares C., Klemens Aleksandryjski, [in:] C. Vidal Manzanares, Pisarze wczesnochrześcijańscy I-VII w., trans. E. BURSKa, Warszawa 2012, p. 116-117.

Vidal Manzanares C., Panten, [in:] C. Vidal Manzanares, Pisarze wczesnochrześcijańscy I-VII w., trans. E. Burska, Warszawa 2012, p. 146.

WĘCOWski M., Sympozjon, czyli wspólne picie. Początki greckiej biesiady arystokratycznej (IX-VII wiek p.n.e.), Warszawa 2011.

Wilkins J.M., Hill S., Food in the Ancient World, Malden-Oxford 2006.

Wit R.E., The Hellenism of Clement of Alexandria, "Classical Quarterly" 25, 1931, p. 195-204.

Wojtczak J., Klemens Aleksandrinos, [in:] Słownik pisarzy antycznych, ed. A. Świderkówna, Warszawa 2001. 
Wojtczax J., Stosunek Klemensa Aleksandryjskiego do filozofii według Stromata, "Studia Theologica Varsaviensia" 9, 1971, p. 263-288.

Wygralak P., Vinum laetificat cor hominis (Ps 104, 15). Ojcowie Kościoła o spożywaniu wina i związanych z tym problemach, "Poznańskie Studia Teologiczne" 25, 2011, p. 141-158.

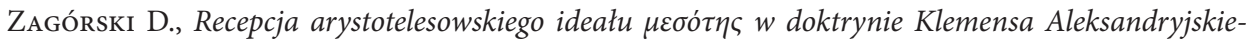
go. Problem definicji, "Roczniki Teologiczne Katolickiego Uniwersytetu Lubelskiego" 51, 2004, p. 5-42.

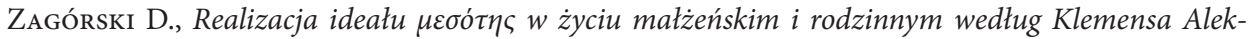
sandryjskiego, "Roczniki Teologiczne Katolickiego Uniwersytetu Lubelskiego" 52, 2005, p. 5-24.

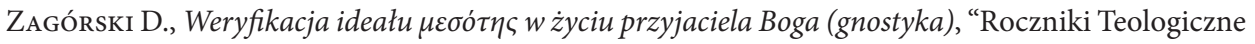
Katolickiego Uniwersytetu Lubelskiego" 54, 2007, p. 99-121.

Zohary D., The Domestication of the Grapevine Vitis vinifera L. in the Near East, [in:] The Origins and Ancient History of Wine, ed. P.E. McGovern, S.J. Fleming, S.H. Katz, Amsterdam 1996, p. 23-30.

Zohary D., Hopf M., Domestication of Plants in the Old World. The Origin and Spread of Cultivated Plants in West Asia, Europe, and the Nile Valley, Oxford 1993.

Abstract. Titus Flavius Clemens was a philosopher and Christian theologian from the period of the $2^{\text {nd }}-3^{\text {th }}$ century. The aim of this paper is to present his view on the subject of wine and his recommendations on wine consumption as described in his work entitled Paedagogus.

In this work Titus Flavius Clemens focuses primarily on the moral side of drinking wine. He is a great supporter of the ancient principle of moderation, or the golden mean ( $\mu \varepsilon \sigma o \dot{\tau}\rceil \varsigma)$. We also find its traces in his recommendations regarding the drinking of wine. First of all, he does not require Christians to be abstinent. Although he considers water as the best natural beverage to satisfy thirst, he does not make them reject God's wine. The only condition he sets, however, is to maintain moderation in drinking it. He recommends diluting wine with water, as the peaceful Greeks always did, unlike the war-loving barbarians who were more prone to drunkenness. On the other hand, Titus Flavius Clemens warns the reader against excessive dilution of wine, so that it does not turn out to be pure water. He severely criticizes drunkenness, picturesquely presenting the behavior of drunks, both men and women. Wine in moderation has, in his opinion, its advantages - social, familial and individual. It makes a person better disposed to himself or herself, kinder to friends and more gentle to family members.

Wine, when consumed in moderation, may also have medicinal properties. Clemens is well aware of this fact and in his work he cites several medical opinions on the subject.

Unfortunately, in Paedagogus we find little information about wine as a food product / as an everyday bevarage. The input on the subject is limited to the list of exclusive, imported wines. What is worth noting, Titus Flavius Clemens appears to be a sommelier in this way.

Keywords: Titus Flavius Clemens, early Christianity, wine, principle of moderation, the golden mean ( $\mu \varepsilon \sigma o ́ \tau \eta \varsigma)$. 


\section{Jolanta Dybała}

University of Łódź The Waldemar Ceran Research Centre for the History and Culture of the Mediterranean Area and South-East Europe Ceraneum ul. Matejki 32/38, room 319 90-237 Łódź, Poland j.dybala@vp.pl

\section{Krzysztof Jagusiak}

University of Łódź The Waldemar Ceran Research Centre for the History and Culture of the Mediterranean Area and South-East Europe Ceraneum ul. Matejki 32/38, room 319 90-237 Łódź, Poland krzysztof_jagusiak@o2.pl

Michał Pawlak pawlak_michal@o2.pl 